\title{
Industry-Institute Interaction : An Important Step Towards Empowering Skills of Engineering Students
}

\author{
Anilkumar Nandi ${ }^{1}$, Jyoti Bali ${ }^{2}$, Kuashik $\mathbf{M}^{3}$, Suhas Shirol ${ }^{4}$ \\ ${ }_{1,2,3,4}$ B.V.B College of Engineering \& Technology, Hubli,India \\ 'anilnandy@bvb.edu, ${ }^{2}$ jyoti_bali@bvb.edu
}

\begin{abstract}
The paper is to discuss about the implications of industry-academia interaction used for effective learning process and skill development in students. Here we share the experience of handling of an event on analog circuit maker contest, designed and developed by Texas Instruments industry, Bangalore and conducted and evaluated by a team of faculty in our academic institution. Here we emphasize on the benefits gained by students and faculty by undergoing the activity. The statistics regarding the level of performance and involvement of students and staff are discussed along with their feedback, which proves that Industry-Institute interaction as a very relevant process in an engineering institute.
\end{abstract}

Keywords-Industry-academia interaction; Analog Circuit maker contest; Texas Instruments; Skill development;

\section{Anilkumar Nandi}

B.V.B College of Engineering \& Technology, Hubli,India anilnandy@bvb.edu

\section{Introduction}

Industry-academia interaction is an important process to be included mainly in engineering curriculum as it can provide necessary inputs to the academic institute to build the competencies required by faculty and students. A major percentage of engineering students join industries immediately after their graduation. Hence the academic institution needs to cater to the demands of industry requirements by equipping students with necessary skill set by designing special activities through association with reputed industry leaders. Even industries will be interested in regular interaction with institutes from which they recruit graduates for jobs so as to project their expectations about the skill set needed from them. Because of global economy, there is a lot of competition among multi-national companies to excel. Hence they look up to training institutes to build student competencies accordingly in institute campus [1]. For such regular interaction, activities like arranging industry visits, taking up industry sponsored projects, establishing an exclusive Industry-Institute Partnership / Interaction Cell, participation of experts from industry in curriculum development, student project evaluation, conduction of demo, lectures, workshops, joint research work carried out along with faculty members from academic institution can be planned [2].

For any engineering course, enabling student learning through Quiz, competition, workshop and seminar involving industry experts are considered to be very effective ways of testing engineering skills of 
students as per industry requirements. Students undergo activities like team formation, division of labour, peer learning, cooperative learning, managing the work concurrently in team against the deadlines to be met. Industry-academia interaction is an important step using which students can gather information and improve their skills, so that they are industry ready. Students do solve problems in theory and lab sessions regularly in the academic environment also. But with the inputs from industry experts, students get a better exposure towards the gaps they should fill in before joining industry. This was well experienced during the event sponsored by Texas Instruments (TI) and conducted at BVBCET campus for electrical stream students.

\section{Literature Survey on Need for Industry Institute Partnership}

We have done literature survey on Industry Institute partnership, which covers the success stories of many institutions having association with the industry partners helping each other's growth in a very meaningful and productive way. As per 2011 report of National Association of Software and Services Companies (NASSCOM), around $75 \%$ of Indian engineering students do not have the basic eligibility for employment [3]. Technical education institutes have to partner with industries to improve the relevance and quality of education especially its practical component. This will help to educate and prepare students to be future-ready. Based on the growing needs to fight tough competition, engineering colleges and industry are closely interacting to create synergies. The academic strength of institutions supported by the practical experience of the industry can help young engineers grow faster. This is in turn a critical requirement of productive interface for the development of any nation in this era of knowledge economy [4].

Industry-institute interaction and cooperation has evolved from the past in the form of industry visits up to sharing of resources in recent times. There can be a wide variety of interactions practiced among industries and institutes through activities on problem solving, curriculum development, study visits, provision of scholarships and apprenticeship training and setup of incubation centre [5]. Industries started the initiative of helping educational institutes in the design, financing, building and operation of projects involving risks only from the time, the concept of public private partnership has evolved and recognized
[6]. Many researchers have emphasized the need for Industry Academic Partnership in sustainable development of technical and vocational education training in the current scenario $[7,8,9,10]$.

\section{Methodologies and Implementation}

The plan of the activity on analog circuit maker contest was done by TI, who designed the methodologies to be followed and gave a set of guidelines to students around 15 days prior to the day of event. A well designed, single question paper to all participant teams and guidelines for the evaluators were given by TI . Students were very enthusiastic to solve problem designed by industry experts. There were around 15 teams participated in the contest, each comprising of 4-5 students in each team .Conduction of the event and evaluation of the work were carried out by a team of faculty members from BVB College,Hubli. TI even sponsored the event by announcing attractive prizes to the winning team. Student teams from Electronics \& Communication, Instrumentation technology, Computer Science and Automation \& Robotics branches participated in the event scheduled for 3 hours. Student teams had to spend 3 hours of time in three phases namely Theoretical analysis, Simulation and Implementation on bread-board. The guidelines were given by TI in the question paper for this 3-stage process. Students were given access to the internet resources to understand the given problem and check for data sheets.

As a first step, students were expected to do the theoretical analysis of the device i.e. instrumentation amplifier by mathematical derivations relating the input signal, output signal, the gain factor and CMRR calculations. Later in the second step, they were expected to study the behaviour of the device through simulation and show the graph of frequency response of instrumentation amplifier to find out $-3 \mathrm{~dB}$ gain, cut off frequency and thus calculate the bandwidth of amplifier. In the third step, student teams were asked to build the circuit using the instrumentation amplifier INA121 on bread board and study its response for the specified input signal. Later they compared the simulation results with that of the practically implemented circuit response plotted using laboratory instruments. Students in different teams break among themselves to share the work among three stages, so that in a group of 4-5 students, subgroups were made to handle subtasks, two of them doing the theoretical analysis, other two doing simulation, later the 
remaining students doing implementation on breadboard.

Sub division of work thus helped them to solve the problem easily by analyzing each of the steps concurrently taking minimum amount of time. Later the entire group sat together discussed and shared each other's work and documented their results in the answer sheet. The event thus accommodated the scope for individual performance in handling the subtask and later for collective performance as a team in completing 3-stage activity. The teams had to complete 3 -stage process in the stipulated time period of 3 hours. Hence all the members of the team were engaged actively rather than volunteering commonly seen during regular lab sessions. Later the evaluation of project developed by students was done with the help of faculty members involved in teaching Electronics subjects. Students were monitored by the faculty team during all the three stages. Students undertook the activity with great enthusiasm and tried to complete the tasks well within the time allotted.

\section{Assessment Methodology Followed}

We followed the assessment methods to verify the level of learning achieved by students as per the valued outcomes of ABET criteria. We need to know the impact of introducing changed practices on the participating students by critical observation and response in terms of feedback. The important objective of assessment was not to evaluate what students answer in the answer sheets but to analyze how they arrived at the solutions and the processes they followed [11]. Here the stress was on measurement of performance of team rather than individual performance.

Evaluation was based on three factors mainly i.e. time taken to complete all three stages, accuracy with which implemented results matched simulation results, level of involvement of students in building solution, management of subtasks within the team and collaborative learning achieved. We collected the statistics of results of competition based on number of students who solved correctly the theoretical analysis, simulation and also implementation respectively. This helped faculty members to get inputs regarding the ways in which the procedures can be refined to improve the experiential learning of students for similar activities to be planned in future course of time.

\section{Results of Implementation and Feedback}

The response of students for this contest organized by TI proved highly encouraging for faculty members. The faculty members involved appreciated the ways, problems can be defined to enable students to solve them effectively by knowing the relevance of following each step of theoretical analysis, simulation and implementation on breadboard. They got very realistic inputs and guidelines from TI industry about the way questions can be set during regular lab sessions as well lab tests. Feedback was taken from students regarding the attainment of benefits, uniqueness of the contest, the expectations they had before and after the conduct of the event. Majority of students expressed their satisfaction and happiness after undergoing the activity through feedback. Students got convinced and expressed that such a 3phase activity can be used for effective conduction of exercise and effective learning. They even expressed that such an experience will definitely help them to prepare for placement interviews and has boosted their confidence level. They were eager to undergo similar contests in future also and solve problems given by experts from Industry. Faculty and students got an exposure towards the factors to be emphasized during design process, importance of acquiring fundamentals of subjects studied, relating simulation results to theoretical analysis and implementation.

A questionnaire was designed to collect student's feedback to check the effectiveness of the event conducted. Statistics regarding the performance of students in groups is collected. Summary of the performance of students and their feedback is shown in Table I. Evaluation of performance of students was done for the activities of individual write-up, simulation of designed circuit, implementation and demo. Questionnaire was designed mainly to collect data from students based on their expectations and achievement of higher skills at the end of activity. The data collected also revealed that students are eager towards such activities in future also, as it helps them build the skill set needed for implementation and testing of electronic circuits. The same information is shown through the bar chart shown in Fig.1. As faculty, we could analyze the advantages of making students follow the 3 stage process of implementing the electronic circuits on regular basis. It is noted that some of the direct benefits are reduced time consumption, increased level of conscious involvement of students, effective team interaction etc. We could note that activities of such kind with the 
involvement of industry experts can enable students to develop some higher skills of the nature listed in Table 1 in a phased manner.

Table 1. Measurement on effectiveness of the event

\begin{tabular}{|c|c|c|c|c|}
\hline $\begin{array}{c}\text { Factors Measured } \\
\text { based on } \\
\begin{array}{c}\text { Performance and } \\
\text { Feedback }\end{array}\end{array}$ & $\begin{array}{c}\text { Strongly } \\
\text { agree }\end{array}$ & Agree & $\begin{array}{c}\text { Dis- } \\
\text { agree }\end{array}$ & $\begin{array}{c}\text { Strongly } \\
\text { disagree }\end{array}$ \\
\cline { 2 - 5 } Team work ability & 60 & 40 & 0 & 0 \\
\hline $\begin{array}{c}\text { Problem solving } \\
\text { ability }\end{array}$ & 43 & 57 & 0 & 0 \\
\hline $\begin{array}{c}\text { Collaborative and } \\
\text { Cooperative learning }\end{array}$ & 69 & 31 & 0 & 0 \\
\hline $\begin{array}{c}\text { Strategic and critical } \\
\text { thinking ability }\end{array}$ & 54 & 46 & 0 & 0 \\
\hline $\begin{array}{c}\text { communication } \\
\text { skills }\end{array}$ & 54 & 46 & 0 & 0 \\
\hline $\begin{array}{c}\text { Self directed } \\
\text { learning }\end{array}$ & 60 & 40 & 0 & 0 \\
\hline Skill development & 54 & 46 & 0 & 0 \\
\hline Integrating approach & 50 & 50 & 0 & 0 \\
\hline $\begin{array}{c}\text { Troubleshooting and } \\
\text { debugging ability }\end{array}$ & 53 & 47 & 0 & 0 \\
\hline
\end{tabular}

The activity addresses many of the important outcomes of ABET a-k criteria through the following:

i) Solving the problem in team (criteria a,b ,c \&e)

ii) Demonstrating professional and ethical responsibility through collaborative learning in team (criteria f)

iii) Use of modern tools for simulation (criteria k)

iv) Conduction of experiment based on the real time problem stated by industry (criteria $b \& j$ )

v) Students could be tested for written communication through the answer sheets (criteriag)

vi) Lifelong learning through the method followed for solving an open ended problem in team (criteria i)

Attainment of various levels of learning outcomes as per ABET criteria are studied through feedback and performance of students as per set objectives and is tabulated in Table II and shown graphically in Fig 2.This activity proved very important as it revealed that the theoretical analysis, simulation and implementation are the processes to be followed in general for any of the problems to be solved even in regular lab sessions. This exercise can help students efficiently use the time allotted for lab by involving each of the student in the team contributing towards any of the three processes.

Thus the design plan and execution of contest could trigger some questions in faculty regarding the ways in which problems can be framed during lab sessions and make students undergo the 3-stage activity of Theoretical analysis, Simulation and implementation consciously. The faculty got the inputs regarding the way they can introduce the methodologies to be followed for improving skills of students better so that more and more students can excel in placement interviews. Small improvements through such activities can contribute towards big difference in student learning and skill development.

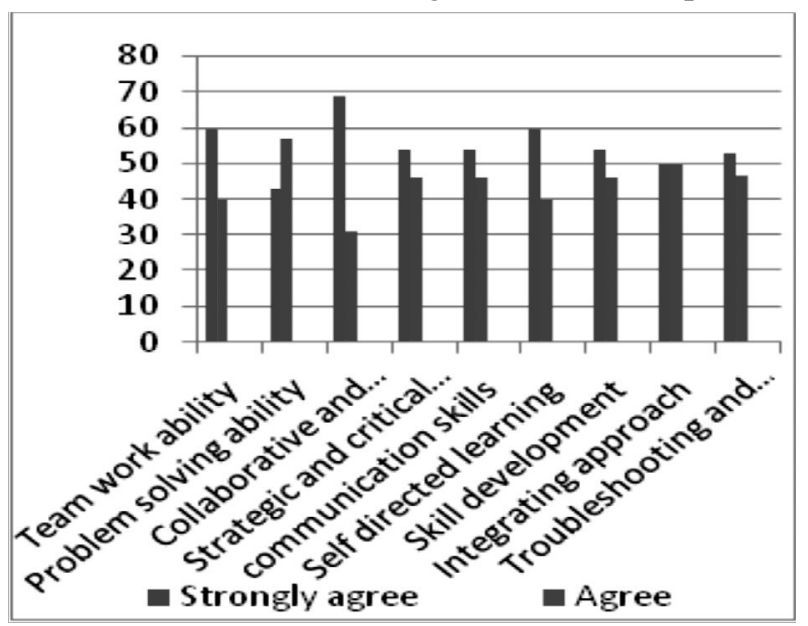

Fig.1 Bar chart of the data collected in Table 1

Table 2 Attainment of a-k criteria

\begin{tabular}{|c|c|c|c|c|}
\hline \multicolumn{5}{|c|}{ Attributes } \\
$\begin{array}{c}\text { Attainment } \\
\text { of learning } \\
\text { outcomes } \\
\text { a-k criteria } \\
(\%)\end{array}$ & $\begin{array}{c}\text { V. } \\
\text { Good }\end{array}$ & Good & $\begin{array}{c}\text { Moder } \\
\text { ate }\end{array}$ & $\begin{array}{c}\text { Not } \\
\text { Satisf } \\
\text { ied }\end{array}$ \\
\hline $\mathrm{a}$ & 60 & 30 & 10 & 0 \\
\hline $\mathrm{b}$ & 75 & 20 & 5 & 0 \\
\hline $\mathrm{c}$ & 70 & 20 & 10 & 0 \\
\hline $\mathrm{f}$ & 80 & 10 & 10 & 0 \\
\hline $\mathrm{g}$ & 76 & 30 & 4 & 0 \\
\hline $\mathrm{i}$ & 71 & 27 & 2 & 0 \\
\hline $\mathrm{j}$ & 83 & 32 & 0 & 0 \\
\hline $\mathrm{k}$ & 86 & 14 & 0 & 0 \\
\hline
\end{tabular}

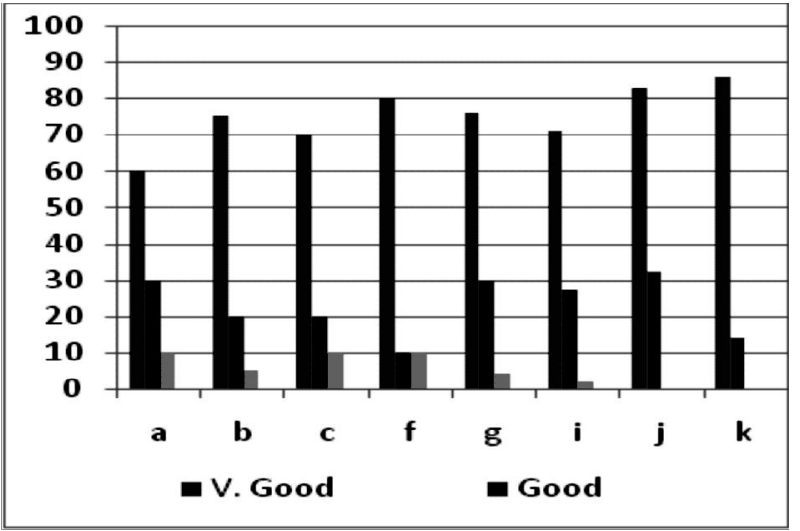

Fig.2 Bar chart of the data collected in Table II 


\section{Conclusion}

We studied table of data and graphs showing the feedback of students on the learning process as well the performance of students in terms of the higher skill competencies demonstrated. Thus faculty can interact with industry experts and design such activities on regular basis to strengthen student skills and knowledge. This was a small step towards enlightening faculty and students to follow standard industry practices to solve the given problem. Industry -Institute interaction can be taken to much higher level by conducting workshops, talks and competitions by industry experts on regular basis. We can refine the methodologies for such events to improve the effectiveness of developing organizational and self management skills of students.

\section{Acknowledgment}

We are thankful to Texas instruments, Bangalore for providing us the resources and guidance for conduction of the event in our institute premises and also the management of BVB College for providing us the opportunity to be part of this event.

\section{References}

[1] Ramaswamy. C, Dr. Brahadeeswaran. D "Establishing Sustainable Industry Institute Partnerships- Case Study Of An Engineering College"

[2] Gopal T V , "Evolving a Sustainable AcademicIndustry Collaboration Model (SAICM)", ELCOT, NSTB and TDB, Singapore at Chennai on 21.08.2000

[3] NASSCOM (2011), Annual Report, New Delhi: National Association of Software and Services Companies.
[4] Larsen, K. (2007), CSR and Labor Issues in a Globalized Economy: Supply Chain Management of MNCs, paper presented at the ADBI training on Enhancing Corporate Social Responsibility, Tokyo.

[5] Majumdar, S. (2008a), Industry-Institute Interaction to Public-Private Partnership: A Journey to Excellence, Paper presented at International Symposium on Public Private Partnership in TVET: Challenges, Opportunities and Best Practices, Dec. 1-2, 2008.

[6]Atienza, T. (2008), University-Industry Collaboration: A Strategy for Sustainable Quality Education Proceedings of the PublicPrivate Partnership in TVET: Issues, Challenges and Best Practices, organized by CPSC, UNESCO-UNEVOC and InWEnt, Manila.

[7] Chakravarty, S.N. (2006), R \& D and Training activity need industry-academic institute interaction, Current Science, Vol.91, No.12.

[8] Murty, V.S. (2002), Interaction between Academia and Industry, Phy. Scr. T97 64-66.

[9] Shollapur, M.R. (2008), "Building Institutions Industry relationship: Indian Experience", University News, 46(13).

[10] Ghatol, A.A., Kaptan, S.S. \& Dhote, K.K. (2004). Industry Institute Interaction, New Delhi: Sarup \& sons.

[11] Hamimi Fadziati A. Wahab, Afida Ayob, Wan Mimi Diyana W. Zaki, Hafizah Hussain, Aini Hussain, Siti Salasiah Mokri, "Program Outcomes Measurement and Assessment Processes", Faculty of Engineering and Built Environment, Universiti Kebangsaan Malaysia, 43600, Bangi, Selangor, Malaysia. 